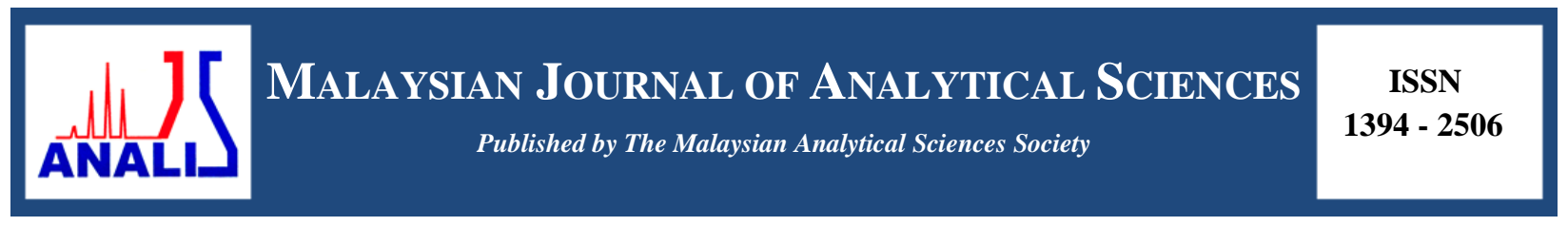

\title{
SYNTHESIS AND CHARACTERIZATION OF MESOPOROUS SILICA MCM-41 AND SBA-15 FROM POWER PLANT BOTTOM ASH
}

\author{
(Sintesis dan Pencirian Silika Mesoporos MCM-41 dan SBA-15 daripada Debu Bawah Loji \\ Janakuasa)
}

\author{
Nurul Barakah Ab Rahman*, Hamizah Md. Rasid, Hashazirah Mohammad Hassan, Mohammad Noor Jalil \\ School of Chemistry and Environment, \\ Faculty of Applied Sciences, \\ Universiti Teknologi MARA, 40450 Shah Alam, Selangor, Malaysia
}

*Corresponding author: barakahrahman@gmail.com

Received: 24 February 2015; Accepted: 27 October 2015

\begin{abstract}
Silica was extracted from power plant bottom ash by alkali fusion method and used to synthesize MCM-41 and SBA-15. As comparison, MCM-41 and SBA-15 were synthesized by using tetraethylorthosilicate (TEOS) as pure silica source. All synthesized MCM-41 and SBA-15 were characterized using X-ray Diffraction (XRD) and nitrogen adsorption to determine the formation of hexagonal pores, Field Emission Scanning Electron Micrograph (FESEM) was used to observe their morphology while Fourier Transform Infrared Spectroscopy (FTIR) was used to obtain the functional group and removal of surfactant after calcinations. XRD results confirmed bottom ash MCM-41 (BA MCM-41), pure SBA-15 (PSBA-15) and bottom ash SBA-15 (BA SBA-15) have well-ordered mesostructures. $\mathrm{N}_{2}$ adsorption of pure MCM-41 (PMCM-41), PSBA-15 and BA SBA-15 indicated type IV isotherm while BA MCM-41 exhibit type III isotherm. According to FESEM analyses, the particle morphology of bottom ash mesoporous silica was different from those prepared using pure chemical. Morphology of PMCM-41 and PSBA15 showed rod like particle while BA MCM-41 and BA SBA-15 exhibited agglomerated particle. PMCM-41, PSBA-15 and BA SBA-15 shows ordered hexagonal, high surface area and narrow pore distribution.
\end{abstract}

Keywords: mesoporous silica, MCM-41, SBA-15

\section{Abstrak}

Silika telah diekstrak daripada abu bawah loji janakuasa melalui kaedah gabungan alkali dan digunakan untuk sintesis MCM-41 dan SBA-15. Sebagai perbandingan, MCM-41 dan SBA-15 telah disintesis dengan menggunakan tetraetilortosilika (TEOS) sebagai sumber silika tulen. Semua MCM-41 dan SBA-15 yang telah disintesis dicirikan menggunakan kaedah pembelauan Sinar X (XRD) dan penjerapan nitrogen untuk menentukan pembentukan liang heksagon, mikroskopi elektron pengimbasan pancaran medan (FESEM) digunakan untuk memerhati morfologi manakala Spektroskopi Inframerah Tranformasi Fourier (FTIR) digunakan untuk mengenalpasti kumpulan berfungsi dan penyingkiran surfaktan selepas pengkalsinan. Keputusan XRD membuktikan debu MCM-41 (BA MCM-41), SBA-15 tulen (PSBA-15) dan debu SBA-15 (BA SBA-15) mempunyai mesostruktur yang teratur. Penjerapan $\mathrm{N}_{2}$ oleh MCM-41 (PMCM-41), PSBA-15 dan BA SBA-15 menunjukkan isoterma jenis IV manakala isoterma jenis III bagi BA MCM-41. Berdasarkan analisis FESEM, morfologi zarah silika mesoporos daripada debu bawah loji janakuasa adalah berlainan berbanding yang disediakan menggunakan bahan kimia tulen. Morfologi PMCM-41 dan PSBA-15 menunjukkan zarah jenis rod manakala BA MCM-41 dan BA SBA-15 wujud sebagai zarah bercampur. PMCM-41, PSBA-15 dan BA SBA-15 mempunyai struktur heksagon yang seragam, luas permukaan yang tinggi dan taburan liang yang kecil.

Kata kunci: silika mesoporos, MCM-41, SBA-15 


\section{Nurul Barakah et al: SYNTHESIS AND CHARACTERIZATION OF MESOPOROUS SILICA MCM-41 AND SBA-15 FROM POWER PLANT BOTTOM ASH}

\section{Introduction}

In year 1990s, the researchers of Mobil Corporation discovered MCM-41 molecular sieves can be synthesized by using an inorganic silicate species and organic template [1]. Tetraethylorthosilicate (TEOS) and sodium silicate $\left(\mathrm{Na}_{2} \mathrm{SiO}_{3}\right)$ were the sources of silicon used by researchers to synthesize mesoporous silica [2]. The features of MCM-41 are high pore volume with large uniform pore size (14-100£), high specific surface area which give advanced advantages over zeolites and have many applications in material sciences, chemistry and biology [3, 4]. MCM-41 exhibit hexagonal packed rod-shaped micelle structure, cubic shape for MCM-48 and MCM-50 in lamellar form [4]. The pore size of MCM-41 and MCM-48 can be controlled and widely used as an adsorbent, support and catalyst [5]. Santa Barbara Amorphous-15 (SBA-15) has same features as MCM-41 but their specific surface area and pore volume smaller than M41S materials with thicker pore walls [6]. Fly ash has a high recycling rate and can be use in various parts of recycling systems while $79 \%$ of bottom ash thrown and only $21 \%$ was used in asphalt or in construction. Researchers had considerable interest in conversion of coal bottom ash and fly ash into zeolites or mesoporous silica materials as MCM-41, MCM-48 and SBA-15 [7]. Recently preparation of mesoporous materials from natural waste such as coal fly ash have been reported [8 -11]. Limited reports have addressed in converting coal bottom ash into mesoporous silica [7, 12]. Chandrasekar et al. [12] synthesized mesoporous MCM41, SBA-15 and SBA-16 from supernatant derived from coal bottom ash. They used additional sodium metasilicate in synthesis of SBA-15 and SBA-16.

In this country, there have been no reports thus far in synthesis of mesoporous silica using natural waste like coal bottom ash as silica source. This research aims to extract silica from lower grade bottom ash and mesoporous materials which are MCM-41 and SBA-15 were synthesized using extracted silica. Instead of using expensive reagent, a cheaper silica source can be used to minimize the high production cost of porous silica materials. Then the mesoporous materials were characterized by X-ray Diffraction (XRD), $\mathrm{N}_{2}$ adsorption desorption, Field Emission Scanning Electron Micrograph (FESEM) and Fourier Transform Infrared Spectroscopy (FTIR) analyses

\section{Chemicals and raw materials}

\section{Materials and Methods}

All the chemicals used were commercial reagent grade and purchased from Merck and Sigma-Aldrich. Coal bottom ash was obtained from Tanjung Bin Power Plant in Pontian, Johor, Malaysia.

\section{Alkali fusion and silicate extraction}

Bottom ash was ground to powder with a mesh size of less than $200 \mu \mathrm{m}$ by using a commercial mixing grinder. The finely ground ash was mix with $\mathrm{NaOH}$ powder at 1:1.2 weight ratio with the sample. The mixture of ash and $\mathrm{NaOH}$ was fused in a furnace at $550{ }^{\circ} \mathrm{C}$ for one hour. The obtained fused mass was cooled to room temperature and ground again to obtain a fine powder with mesh size less than $100 \mu \mathrm{m}$. The fine powder of fused mixture was mixed with distilled water at 1:4 ratios and stirred for 24 hours. The solution was centrifuged and filtered. The supernatant will be used for the synthesis of mesoporous silica [12].

\section{Synthesis of MCM-41}

An amount $1.2 \mathrm{~g}$ of cetyltrimethylammonium bromide (CTABr) was dissolved in $15 \mathrm{~g}$ of water and $1.0 \mathrm{~g}$ of ammonium hydroxide $\left(\mathrm{NH}_{4} \mathrm{OH}\right)$. The solution was stirred for 30 minutes. Next, $40 \mathrm{~mL}$ of bottom ash supernatant was slowly added to the homogeneous solution under stirring and stirring maintained for 2 hour. The synthesis $\mathrm{pH}$ was adjusted to 10 using dilute acetic acid. Then the stirring was continued for another 30 minutes. The gel product was heated in an oven at $100{ }^{\circ} \mathrm{C}$ for 48 hours. The solid product was filtered, washed and dried at $100{ }^{\circ} \mathrm{C}$. The product was calcined at $550{ }^{\circ} \mathrm{C}$ for 8 hours. For comparison, pure MCM-41 was synthesized by using TEOS as silica source same as previous procedure [12].

\section{Synthesis of SBA-15}

Template for synthesis of SBA-15 is amphiphilic triblock polymer of Pluronic P123 $\left(\mathrm{EO}_{20} \mathrm{PO}_{70} \mathrm{EO}_{20}\right)$. An amount $4.0 \mathrm{~g}$ of P123 was dissolved in $30 \mathrm{~mL}$ of deionised water and $120 \mathrm{~mL}$ of $2 \mathrm{M} \mathrm{HCl}$ and was stirred at $35{ }^{\circ} \mathrm{C}$ for 20 hours. Then, an amount $8.5 \mathrm{~g}$ of bottom ash supernatant was slowly added under vigorous stirring for 15 minutes. The mixture was kept under static conditions at the same temperature $\left(35^{\circ} \mathrm{C}\right)$ for 20 hours. The milky mixture was 
transferred to an oven at $90{ }^{\circ} \mathrm{C}$ for 24 hours. For comparison, a pure SBA-15 was synthesized by using TEOS as silica sources same as previous procedure. The solid products were filtered, washed and dried at $45^{\circ} \mathrm{C}$ for 72 hours. The products were calcined at $500{ }^{\circ} \mathrm{C}$ for 6 hours [13].

\section{Characterization studies}

X-Ray Diffraction (XRD) patterns of the synthesized samples were determined by using Rigaku D/max-2500 powder diffractometer with $\mathrm{Cu}-\mathrm{K} \alpha$ source $(\lambda=1.5418 \AA, 40 \mathrm{kV}, 40 \mathrm{~mA}) . \mathrm{N}_{2}$ adsorption isotherm and BET surface area were obtained at 77K on a Micromeritics ASAP 2010 Volumetric Adsorption Analyzer. Carlzeiss Supra 40 VP Field Emission Scanning Electron Microscopy (FESEM) was used to characterize the particle size and morphology of mesoporous silica synthesized. Functional groups and removal of surfactant in samples were analyzed from FTIR spectra obtained by using Perkin-Elmer Spectrum One FTIR spectrometer.

\section{X-Ray Diffraction (XRD)}

\section{Results and Discussion}

The XRD pattern of bottom ash MCM-41 (BA MCM-41) (Figure 1a) exhibits an intense (100) signal and three higher order reflections of (110), (200) and (210) planes which confirm the sample is well-defined hexagonal MCM-41[14]. Pure SBA-15 (PSBA-15) in (b) shows three well resolved diffraction peaks which are corresponding to the (100), (110) and (200), indicating hexagonal symmetry with the $p 6 \mathrm{~mm}$ space group. As a comparison, the XRD pattern of BA SBA-15 in (c) indexed an intense (100) peak while the other two peaks (110) and (200) were not resolved as well as those in pure SBA-15 $[12,15]$.

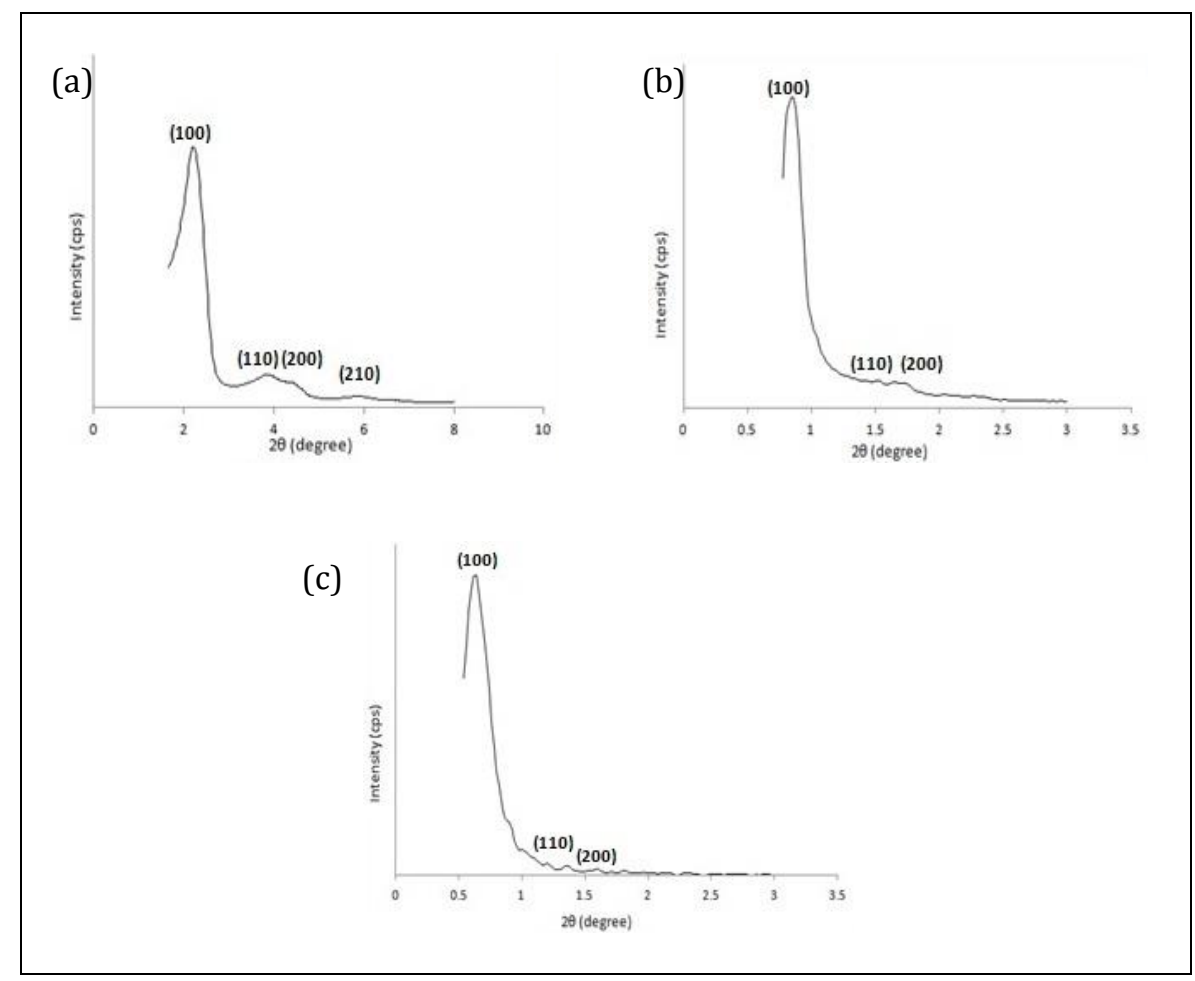

Figure 1. XRD patterns of (a) BA MCM-41, (b) PSBA-15 and (c) BA SBA-15

\section{Nitrogen adsorption desorption}

Figure 2 shows the nitrogen adsorption isotherms of calcined MCM-41 and SBA-15 synthesized from bottom ash and TEOS. PMCM-41 in (a) featured hysteresis loops with the sharp adsorption and desorption branches, which 
exhibit type IV isotherm [16]. The adsorption branches of PMCM-41 located at $\mathrm{P} / \mathrm{P}_{0}$ from 0.4 to 0.5 . Figure $2 \mathrm{a}$ inset shows the pore size distributions (PSDs) for PMCM-41 sample, indicate maxima of $47.75 \AA$. BA MCM-41 (Figure 2b) shows type III isotherm which attributed to the adsorption on macroporous materials [13]. Nitrogen isotherms for PSBA-15 (Figure 2c) and BA SBA-15 (Figure 2d) shows hysteresis loop at P/ $\mathrm{P}_{0}$ from 0.44 to 0.98 and 0.74 to 0.98 respectively. The both isotherms were similar to those reported in the literatures which are type IV. The sharpness of adsorption branches indicate the narrow pore size distribution[17]. Table 1 presents a summary of physicochemical of calcined mesoporous silica synthesized from bottom ash and pure chemical. The specific surface area $\left(\mathrm{S}_{\mathrm{BET}}\right)$ of PMCM-41 was $561.39 \mathrm{~m}^{2} / \mathrm{g}$ with a pore volume of $0.406 \mathrm{~cm}^{3} / \mathrm{g}$ whereas the corresponding values of BA MCM-41 were $5.25 \mathrm{~m}^{2} / \mathrm{g}$ and $0.00477 \mathrm{~cm}^{3} / \mathrm{g}$, respectively. PSBA- 15 has $509.41 \mathrm{~m}^{2} / \mathrm{g}$ surface area and $0.497 \mathrm{~cm}^{3} / \mathrm{g}$ pore volume. The surface area and pore volume of BA SBA-15 decrease to $71.40 \mathrm{~m}^{2} / \mathrm{g}$ and $0.204 \mathrm{~cm}^{3} / \mathrm{g}$ respectively.

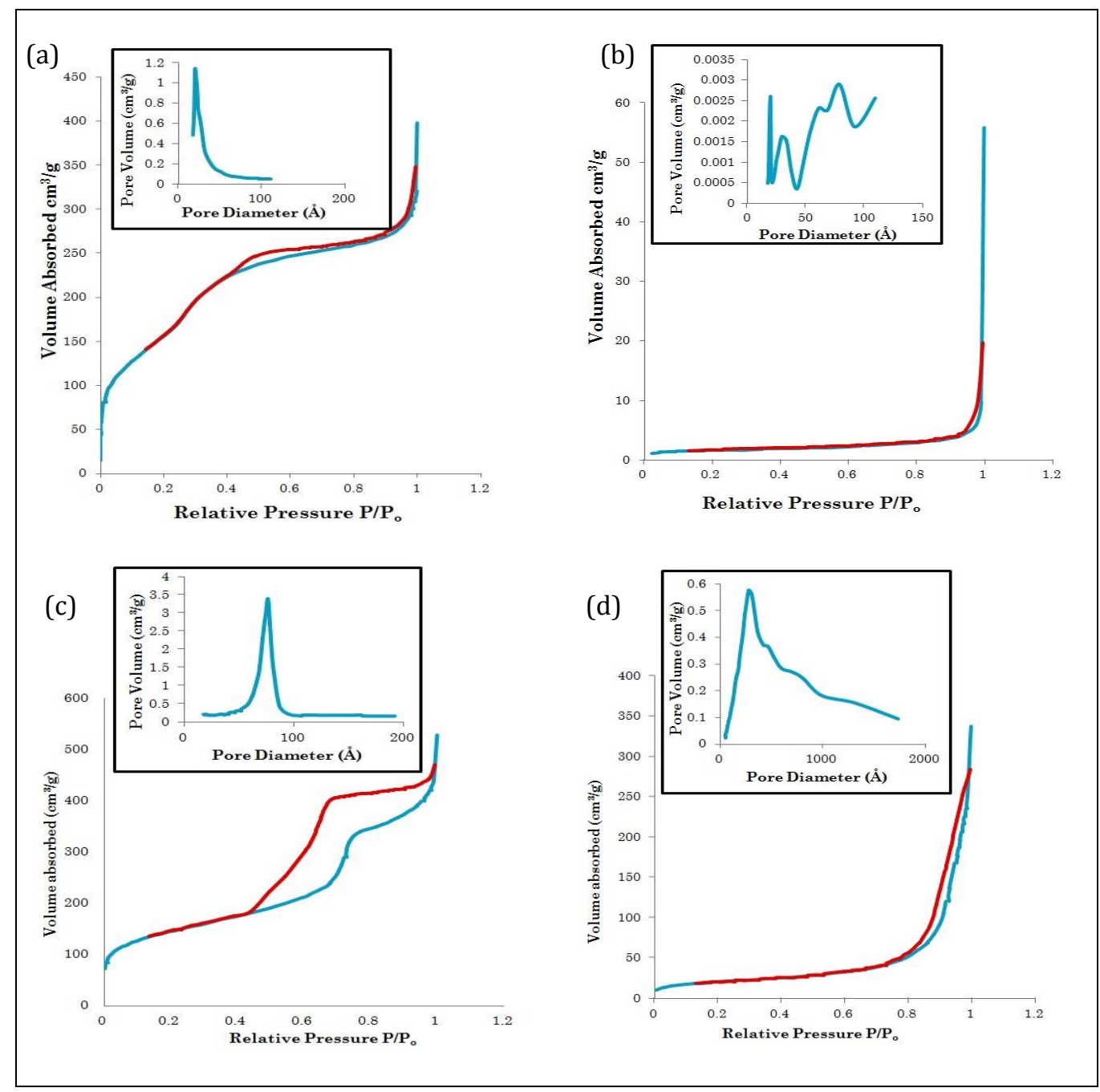

Figure 2. Nitrogen adsorption isotherms and pore size distributions (inset): (a) PMCM-41, (b) BA MCM-41, (c) PSBA-15 and (d) BA SBA-15 
Table 1. Physicochemical of calcined mesoporous silica synthesized from bottom ash and pure chemical

\begin{tabular}{llll}
\hline Types of mesoporous silica & $\begin{array}{l}\mathbf{S}_{\text {BET }} \\
\left(\mathbf{m}^{2} / \mathbf{g}\right)\end{array}$ & $\begin{array}{l}\mathbf{V}_{\mathbf{p}} \\
\left(\mathbf{c m}^{\mathbf{3}} / \mathbf{g}\right)\end{array}$ & $\begin{array}{l}\mathbf{D}_{\text {pore }} \\
(\mathbf{A})\end{array}$ \\
\hline PMCM-41 & 561.39 & 0.406 & 47.75 \\
BA MCM-41 & 5.25 & 0.00477 & 1009.32 \\
PSBA-15 & 509.41 & 0.497 & 84.71 \\
BA SBA-15 & 71.40 & 0.204 & 315.65 \\
\hline
\end{tabular}

\section{Field Emission Scanning Electron Micrograph (FESEM)}

Figure 3 displays the FESEM micrograph of all synthesized mesoporous silica materials. PMCM-41 (a) and PSBA15 (c) shows rod like. Particle morphology of BA MCM-41 and BA SBA-15 exhibit agglomerated particles of 1 to $3 \mu \mathrm{m}$ in diameter [16].

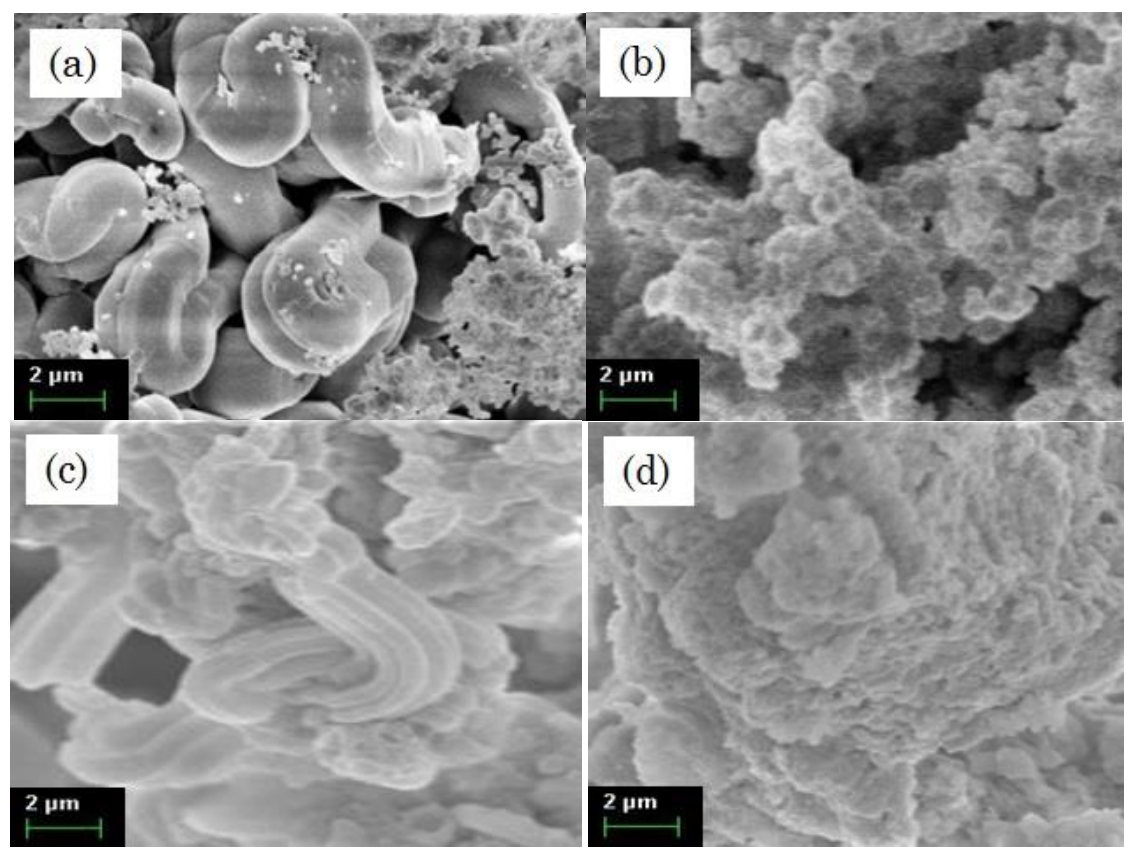

Figure 3. Morphology of: (a) PMCM-41, (b) BA MCM-41, (c) PSBA-15 and (d) BA SBA-15

\section{Fourier Transform Infrared (FTIR)}

The infrared spectrum of synthesized materials in the region of $4000-400 \mathrm{~cm}^{-1}$ recorded at ambient condition with $\mathrm{KBr}$ technique shown in Figure 4 (a) and (b), respectively. For calcined MCM-41 (Figure 4a: (ii), (iv)) and calcined SBA-15 (Figure 4b: (ii), (iv)), the bands around $2920 \mathrm{~cm}^{-1}$ and $2850 \mathrm{~cm}^{-1}$ assigned for the long chain of alkyl group of surfactant molecules were disappeared after calcinations due to the removal of surfactants. The FTIR spectra of MCM-41 and SBA-15 shows the intense bands at $1097.43-1067.25 \mathrm{~cm}^{-1}$ attributes for asymmetric stretching Si-OSi bonds while $806.63-792.92 \mathrm{~cm}^{-1}$ bands indicates the symmetric stretching Si-O-Si bonds. The bands at $965.75-$ $941.68 \mathrm{~cm}^{-1}$ and $474.69-466.46 \mathrm{~cm}^{-1}$ accounts for the stretching and bending vibrations of surface $\mathrm{Si}-\mathrm{O}^{-}$groups [18]. 


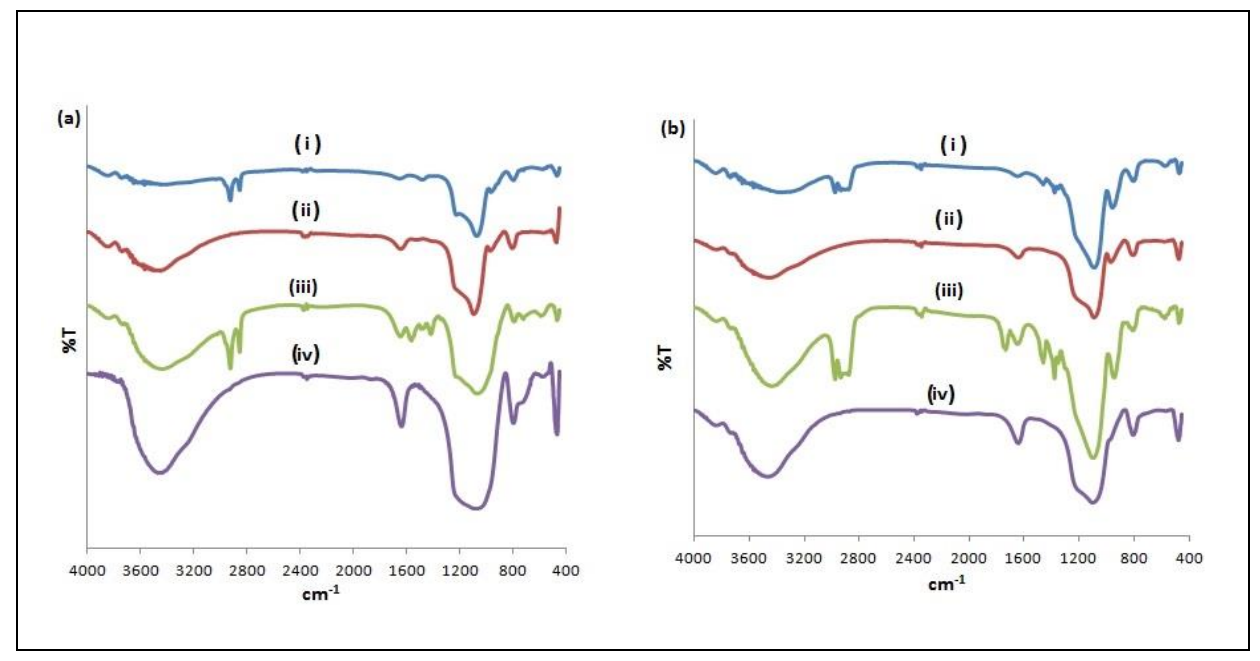

Figure 4. (a) IR spectra of MCM-41: (i) Uncalcined PMCM-41, (ii) Calcined PMCM-41, (iii) Uncalcined BA MCM-41 and (iv) Calcined BA MCM-41; and (b) IR spectra of SBA-15: (i) Uncalcined PSBA-15, (ii) Calcined PSBA-15, (iii) Uncalcined BA SBA-15 and (iv) Calcined BA SBA-15.

\section{Conclusion}

Characterization results indicated PMCM-41, PSBA-15 and BA SBA-15 were successfully synthesized. They exhibited ordered hexagonal, high surface area and narrow pore distributions. According to $\mathrm{N}_{2}$ adsorption desorption analyses, the porous structure of BA MCM-41 was destroyed after calcinations. The synthesis of SBA15 by using silica source from bottom ash supernatant was better than MCM-41. MCM-41 and SBA-15 synthesized from pure chemical was superior compared to those syntheses from bottom ash supernatant.

\section{Acknowledgement}

The authors would like to thank the Ministry of Higher Education (MOHE) for financing the project under the Fundamental Research Grant Scheme no: 600-RMI/FRGS 5/3 (59/2013). Special thanks to Tanjung Bin Power Plant Pontian Johor for the supplied coal bottom ash and highly appreciation to Faculty of Applied Sciences and Faculty of Pharmacy Universiti Teknologi MARA (UiTM) for facilities in completing this research.

\section{References}

1. Zhao, X. S., Lu, G. Q. (Max) and Millar, G.J. (1996). Advances in mesoporous molecular sieve MCM-41. Industrial and Engineering Chemical Research 35 (7): 2075 - 2090.

2. Liou, T.-H. (2011). A green route to preparation of MCM-41 silicas with well ordered mesostructure controlled in acidic and alkaline environments. Chemical Engineering Journal, 17: 1458 - 1468

3. Huang, L., Huang, Q., Xiao, H., and Eić, M. (2007). Effect of cationic template on the adsorption of aromatic compounds in MCM-41. Microporous and Mesoporous Materials, 98(1-3): 330 - 338.

4. Vartuli, J. C., Roth, W. J. and Degnan, T. F. (2008). Mesoporous materials (MS41S): From discovery to application, in Dekkar Encyclopedia of Nanoscience and Nanotechnology: 1797 - 1811.

5. Tatsumi, T., Koyano, K. A., Tanaka, Y. and Nakata, S. (1999). Mechanical Stability of Mesoporous Materials, MCM-48 and MCM-41. Journal of Porous Materials, 6: 13 - 17.

6. Andersson, J, and J Rosenholm, (2008). Mesoporous silica : an alternative diffusion controlled drug delivery system. Topics in Tissue Engineering: 1 - 19.

7. Park, J. E., Youn, H. K., Yang, S. T, and Ahn, W. S. (2012). $\mathrm{CO}_{2}$ capture and MWCNTs synthesis using mesoporous silica and zeolite 13X collectively prepared from bottom ash. Catalysis Today, 190: 15 - 22. 
8. Majchrzak-Kuceba, I. and Nowak, W. (2011). Characterization of mesoporous materials derived from polish fly ashes. International Journal of Mineral Processing. 101: 100 - 111.

9. Hui, K. S., and Chao, Y. H. (2006). Synthesis of MCM-41 from coal fly ash by a green approach: Influence of synthesis pH. Journal of Hazardous Materials, 137: 1135 - 1148.

10. Halina, M., Ramesh, S., Yarmo, M. A. and Kamarudin, R.A. ( 2007). Non-hydrothermal synthesis of mesoporous materials using sodium silicate from coal fly ash. Materials Chemistry and Physics, 101: $344-$ 351.

11. Chang, H. L., Chun, C. M., Aksay, I. A. and Shih, W. H. (1999). Conversion of fly ash into mesoporous aluminosilicate. Industrial \& Engineering Chemistry Research 38: 973 - 977.

12. Chandrasekar, G., You, K. S., Ahn, J. W. and Ahn, W.S. (2008). Synthesis of hexagonal and cubic mesoporous silica using power plant bottom ash. Microporous and Mesoporous Materials. 111: 455 -462.

13. Jalil, M. N., (2011). The preparation and characterization of mesoporous films for electrochemical applications. Ph.D. Thesis. University of Manchester, United Kingdom: pp 249.

14. Ng, E-P, Goh, J-Y, Ling, T. C., and Mukti, R. R. (2013) .Eco-friendly synthesis for MCM-41 nanoporous materials using the non-reacted reagents in mother liquor. Nanoscale Research Letters, 8(1): 120.

15. Du, G., Lim, S., Pinault, M., Wang, C., Fang, F., Pfefferle, L. and Haller, G., (2008). Synthesis, characterization, and catalytic performance of highly dispersed vanadium grafted SBA-15 catalyst. Journal of Catalysis, 253(1): 74 - 90.

16. Ahmad, A., Rasid, H. M. and Kassim, K. (2013). Physicochemical properties of $\mathrm{CuO}_{2}$ (acac)2 supported on functionalized MCM41 containing thiourea ligand. International Journal of Chemical Engineering and Applications, 4(1): 6 - 10.

17. Kruk, M. and Jaroniec, (2000). Characterization of the porous structure of SBA-15. Chemistry Material, 12: $1961-1968$.

18. Fonseca, L. C., Faez, R., Camilo, F. F. and Bizeto, M. A. (2012). Evaluation of the doping process of polyaniline produced inside the mesopores of a sulfonic acid grafted MCM-41. Microporous and Mesoporous Materials 159: 24 - 29. 